\title{
What's in a Name? Unpacking Students' Roles in Higher Education Through Neoliberal and Social Justice Lenses
}

\begin{abstract}
There has been an increase in research and practice exploring how students can gain agency to shape their higher education experiences. Numerous terms evoking certain metaphors have entered the discussions around engaging students, from students as consumers or producers, to students as creators, partners, or change agents. There is scope within the evolving literature to explore the differentiations between these metaphors and the ways that underlying assumptions ultimately shape our practices and research. We unpack the five metaphors frequently used to redefine students' roles in higher education. We then engage in a dialogue across differences, highlighting how our own two distinct perspectives on student engagement-grounded in neoliberalism and social justice-align, overlap, differ, and provide constraints or affordances for student engagement. We offer a critical and reflective commentary questioning the drivers of students' changing roles in higher education in the hope of inviting others into generative dialogue toward expanding the evolving field of student engagement.
\end{abstract}

\section{KEYWORDS}

students as partners, co-creation, higher education, student engagement, students as change agents

\section{INTRODUCTION}

In recent decades, there has been a plethora of terms used to describe the changing roles of students in terms of their engagement, participation, and agency in higher education, among them consumers, partners, co-creators, change agents, and producers (Kay, Dunne, \& Hutchinson, 2010; Kay, Owen, \& Dunne, 2012). Much of this work stems from previous literature on student voice (e.g., Shah \& Nair, 2006), some of which Seale (2009) notes has been evaluative rather than focused on how to conceptualise the types of participation. The growing emphasis on metaphoric representation, for example situating students as partners or producers, "prompts us to re-envision our roles, relationships, and work in teaching and learning" (Matthews et al., 2019, p. 5). The language we use to describe such work can provoke selfreflection, practice, and theory, as each term often takes on complex meanings and perspectives in how one sees students' changing roles.

There has been a rapid increase in both the popularity of such terminology and the seriousness with which institutions broach the terms and practices. Engaging students as partners, for example, is increasingly being integrated into university strategy and policy documents (e.g., Elon University, 2018; 
La Trobe University, 2018; McMaster University, 2018; University of Queensland, 2016; Western Sydney University, 2018) and partnership agreements (e.g., Australian National University, 2017; University of Edinburgh, 2018). The adoption of these terms by individuals and institutions arguably responds to multiple different bodies of research and discourses across the sector.

As the uptake of such terms proliferates, it is a useful time to take stock: to understand how different terms overlap and differ, and, given that language is critical in shaping our thoughts and actions, how the rationales underlying these metaphors might influence assumptions and practices. It is also an appropriate time to reflect on the historical and contextual underpinning of various authors' chosen metaphors to help support future practice and research in the area. McCulloch (2009, p. 171) argues that such student engagement metaphors "are powerful, and serve to structure perceptions and, thereby, actions" and therefore deserve further critical examination.

It is important to acknowledge our academic positionality in conducting such a critical examination. Each of us has been involved in the student engagement field for a number of years. We come to this area with vastly different rationales for doing so, seated in two different ideological, theoretical, and epistemological viewpoints: neoliberalism and social justice. As these ideologies and their inherent values shape each of our perspectives, they also shape our perceptions of each metaphor relating to student agency. Through the co-creation of this article and our shared belief in the importance of students' engaging meaningfully and actively within their university experience, we argue that our two distinct lenses (neoliberalism and social justice) are not necessarily oppositional, but rather are often intertwined in student engagement practices. Practitioners may learn from both rather than having to choose between them. Importantly, in arguing that social justice and neoliberalism are not as mutually exclusive as some assume, our key thesis is that both — together and distinctly — bring value to our discussions about student learning and engagement. Thus, we see the interstices between these positions as potentially generative - a view we explore in the following.

In this article, we introduce, define, and differentiate five metaphors used in literature and practice to discuss students' changing roles in higher education: students as consumers, producers, cocreators, partners, and change agents. We then engage in dialogue-drawing on our own experiences and previous scholarship - to discuss two rationales that can be seen to underpin those metaphors (neoliberalism and social justice). We touch on these rationales in the section on metaphorsacknowledging that people bring a multitude of rationales to such work-but our exploration comes into greater focus through the dialogue we offer. Finally, we explore the implications of these discussions for practitioners and highlight the importance of understanding and intentionality in choosing to adopt such metaphors and practices with reflection on the resulting implications for student engagement.

First, however, we share our positions and assumptions in coming to this work in order to acknowledge our own privileges and biases in choosing to present just two of the potential lenses to this work. In doing so, we follow the example of bell hooks (1989), who argues that making these acknowledgments is important in presenting ourselves not as authorities on these topics but as engaged practitioners who seek to further our own understandings of theory and practice and to open the conversation to others who, from diverse positions, have different but equally valuable perspectives to contribute. 


\section{WHO WE ARE}

We are two early career academics in higher education research and development. Lucy is from Australia, working in Scotland; Mollie is American, working in Australia. Thus, we bring experiences of having studied and functioned within varied international contexts. Our first acknowledgment in coming across each other-initially through our written works - was that we broach this field from radically different stances. In the spirit of openness, we use our first names in labeling our turns in the dialogue.

\section{Mollie}

I came to my research on student-staff co-creation and the student experience from my own unsatisfactory undergraduate education in the United States. I felt strongly that universities were not doing enough to speak to students and hear their voices. My perspective was grounded in market orientation (an output of deregulation and privatization supported by neoliberal agendas; see Connell, 2013): I believed universities were underutilizing student resources (such as perspectives and ideas) when they could be tapping into this knowledge pool to improve services and offerings. For my doctoral thesis, I leaned heavily on organizational literature from industry that discusses a popular management and marketing approach called value co-creation, which encourages user-organizational interactions to boost value for users and, eventually, the organization, through relevant user feedback. This lens further aligned to my belief that both universities and students would need to see the direct benefits for them in order to be incentivized to participate in dialogue.

\section{Lucy}

I came to work and research in field of the students as partners as a postgraduate student in Australia. My rationale and passion for engaging in these practices has become fundamentally seated in social justice. The broadest definition of social justice is the view that everyone should have just access to wealth, resources, opportunities, and privileges. The application of a social justice lens to higher education raises questions about and makes arguments for striving for equity and justice for all within the higher education community in light of existing disparities (Brennan \& Naidoo, 2008). These are important issues given that higher education systems were arguably designed by the privileged for the privileged and, despite ongoing efforts to promote equity, are still systems that are structurally hierarchical and inequitable in terms of power, access, and resources (e.g., Kuh, O’Donnell, \& Schneider, 2017). I see partnership — at its most aspirational — as one means to disrupt this hierarchical status quo in higher education and strive for more equitable ways of working, thinking, and producing knowledge based on the acknowledgment that everyone has valuable expertise to contribute.

\section{Mollie and Lucy}

Rather than see these seemingly oppositional standpoints as divisive, we aim to bring the coalition of our experience and knowledge together in generative ways that complicate and deepen our (and, we hope, others') understandings of student engagement in higher education.

\section{UNDERSTANDING STUDENTS' CHANGING ROLES}

In this section, we introduce, define, and differentiate five metaphors used in literature and practice to discuss students' changing roles in higher education: (1) students as consumers, (2) students 
as producers, (3) students as co-creators, (4) students as partners, and (5) students as change agents. McCulloch (2009) introduced the importance of deconstructing metaphors for students' roles in higher education through his analysis of the student as consumer metaphor. Morgan (2006) similarly writes that while metaphors can be commonly written off as semantic fluctuations, they do in fact represent a way of thinking that illuminates not only current perceptions but also the prevailing likelihood of those perceptions to be repeated. Minnich (2018), in a recent keynote, used the following metaphor: if higher education is a train that trundles along in a certain direction, it is critical that we, the members of the university community, occasionally get off that train to question direction in which we are travelinglest we all fall into the trap of banality regarding our own assumptions and practices. It is important, then, that the metaphors that increasingly influence the direction in which this academic train is traveling continue to be examined.

\section{Students as consumers}

The metaphor positioning students as consumers and the subsequent debates that followed have been prominent in higher education discourses for decades (McCulloch, 2009; Monroe, 1973). Arising from the introduction of fees and increased managerialism in many Western-style higher education systems, seeing students as (fee-paying) consumers often positions students as actors in a neoliberal (that is, free market) state, where they take on customer-like behaviors and are increasingly seen as sources of revenue (Tilak, 2015; Woodall, Hiller, \& Resnick, 2014). The metaphor of students as consumers thus evokes a higher education state where students pay fees and, in exchange, consume educational experiences towards their degree. Universities, in this context, focus increasingly on key performance indicators that track both students' ongoing consumption and the likelihood that they will consume again, such as student satisfaction and loyalty. These indicators are easy to benchmark (Woodall, Hiller, \& Resnick, 2014 yet doing so often comes at the expense of holistic understandings of value. For example, complex dimensions of the university experience, such as student employability, may be superficially equated to first job after graduation; or the enjoyment of the student experience may be equated to word-of-mouth recommendations (Barnacle \& Dall'Alba, 2017; Dollinger, 2018a; Harvey, 2001).

While it is credible to see that with rising fees and increased marketization of higher education, students and universities may perceive students as consumers more so now than ever before, numerous criticisms of the metaphor have been voiced. Scholars have pointed out that the metaphor of students as consumers is inappropriately applied to the university context: it positions learning as a product rather than a processes (McCulloch, 2009); it can encourage an entertainment model of learning (where educators need to keep their "consumers" happy) that can detrimentally affect pedagogy and curriculum (McMillan \& Cheney, 1996); and it supports disproportionate student entitlement (Singleton-Jackson, Jackson, \& Reinhardt, 2010). McCulloch (2009) concluded that, while the metaphor has some select alignment to the higher education context, it is an inappropriate metaphor overall for the sector. McCulloch, as a pushback against such consumerism, instead encourages scholars to reframe the metaphor, positioning students as producers. 


\section{Students as producers}

The idea of students as producers arose within the past twenty years as a rebuke against the traditional "sage on the stage" model of higher education, whereby students were positioned as empty vessels or passive learners who absorb knowledge from more learned others. Freire (1972) critically coined this as the "banking model of education," which frames students as passive recipients of knowledge. The metaphor positioning students as producers challenges this status quo by arguing that all knowledge in higher education is co-produced by those who interact in university communitiesincluding students (Hennig-Thurau, Langer, \& Hansen, 2001). Therefore, unlike the metaphor of students as consumers, where universities are responsible to their students, the metaphor of students as producers highlights the intellectual and experiential value students bring to higher education (Neary \& Winn, 2009). Thus, while the terms are not necessarily at odds with one another, they to focus on different aspects of the student roles or situated place.

To illustrate the idea of students as producers in practice, co-production can occur on an individual level as students co-produce their education through socialization, interaction, and knowledge formation in university environments (Kotzé \& du Plessis, 2003). This example draws on constructivism as students construct knowledge both internally (e.g., cognitive constructivism) and socially (e.g., social constructivism) to develop their own learning and understandings (see Amineh \& Asl, 2015). Yet the metaphor of students as producers is not only a means to understanding how students learn individually, but it can also be deployed as an example of how universities can learn with students, for example, students carrying out co-research as facilitated by teachers (Neary \& Winn, 2009). Other examples of students co-producing for others include students producing podcasts or YouTube videos as curricular learning resources (Keegan \& Bell, 2011; Lee, McLoughlin, \& Chan, 2006). Students in higher education, when positioned as producers, are seen to hold responsibility for and an important role in knowledge production in ways that align more closely with social justice rationales for engagement (Neary \& Winn, 2009). In another example, final-year students in an engineering course produced short animated videos for first-year students in which the critical concepts they would soon learn in class were applied in the work environment by professional engineers (Loch \& Lamborn, 2016). This example (and many others) challenges the tradition that staff must create learning resources or knowledge, and it explicitly values students' diverse perspectives. In a sector where focus is increasingly placed on accounting for rapidly diversifying student cohorts, drawing on and including students' diverse experiences in the production of such resources can go a long way to creating more inclusive learning environments. Such a goal and outcome agrees with a social justice approach to education where access is equitable and inclusion is core.

Neary (2014) has argued that understanding students as producers involves more than supporting students to co-produce teaching and learning; rather, it is an overarching idea that speaks to purpose of higher education. He explains that at the University of Lincoln, the concept of student as producer has led academics, students, and professional staff to collaborate toward a range of projects and outcomes (Neary, 2014). This sentiment is further echoed by researchers who advocate for students' roles to be repositioned as both consumers of higher education and producers who bring much-needed diversity to the creation of knowledge (Smith, 2000). In some ways, the metaphor of students as producers can be seen to provide a foundation for other ways of engaging students, such as students as co-creators and partners, as it embraces the value that students bring with them when they enter the 
university and their contributions to the production of knowledge and change through both coproduction initiatives and their everyday (inter)actions.

\section{Students as co-creators}

The metaphor that situates students as co-creators is one possible direction from which to build on the concept of students as producers. The term co-creation, with roots in organizational literature (see Prahalad \& Ramaswamy, 2004), recognizes students as knowledge producers and further posits that students have valuable resources, such as perspectives, ideas, opinions, and experiences, which can invigorate higher education (Dollinger, 2018b; Sanders \& Stappers, 2014). The metaphor of students as co-creators in higher education has often been positioned within the lens of social justice-for example, students having the right and responsibility to co-create their own studies (Bovill, Cook-Sather, \& Felten, 2011; Seale, Gibson, Haynes \& Potter, 2015). However, it also can be situated within neoliberalism, as students can add value to other students and to the university (Judson \& Taylor, 2014). The metaphor of students as co-creators therefore is a good example of how terms and metaphors do not necessarily align to a single frame or lens and are often deployed in a multitude of contexts and by individuals with diverse motivations and rationales.

We see ambiguity when comparing the metaphors students as producers and students as cocreators. Though one could argue that while the metaphor of students as producers could be framed as describing both an individual process (producers of their own knowledge) and a group process (coproducers of resources, see section above), the metaphor of students as co-creators describes only group endeavors-hence the permanent co-. For example, it describes processes through which staff seek to co-create teaching approaches, courses, or curricula with students - often with an explicit outcome in mind (Bovill, Cook-Sather, \& Felten, 2011). However, as the terms have frequent crossover in literature, we acknowledge that this distinction may not always be explicit or appropriate.

Sanders and Simons (2009) define co-creation broadly as "any act of collective creativity that is experienced jointly by two or more people.” This could extend co-creation activities to other collaborative activities, such as co-governance (Varnham, 2017) and student participation in workintegrated learning subjects or opportunities (Dollinger \& Brown, 2019; Hammersley, Lloyd, \& Bilous, 2018). These activities, similar to the co-creation of teaching approaches and curricula, encourage ongoing dialogue between students and staff, from the design of the activity or process to the outputs and eventual dissemination. This distinguishes co-creation from other collaborative acts, such as codesign (commonly discussed in design literature), which emphasises the final product's design and utility (Kleinsmann \& Valkenburg, 2008). Co-creation focuses not only on output but also on process and continuing development (Freire \& Sangiorgi, 2010).

\section{Students as partners}

The metaphor of students as partners has been defined as a "collaborative, reciprocal process through which all participants have the opportunity to contribute equally, although not necessarily in the same ways, to curricular or pedagogical conceptualization, decision making, implementation, investigation, or analysis" (Cook-Sather, Bovill, \& Felten, 2014, pp. 6-7). This term arose in higher education around two decades ago, drawing on work in K-12 education, where student voice and partnership have been modes of practice for much longer. Such partnership is potentially radical work in 
higher education institutions, which are traditionally hierarchical, as partnership can create liminal spaces within which power and exclusion can be deconstructed, critiqued, and potentially redressed (Cook-Sather \& Alter, 2011; Mercer-Mapstone \& Mercer, 2018). Such transformation occurs through the reconceptualization of relationships between staff and students-seeing that relationship as a space for mutual empowerment among co-learners with different but equally valuable expertise to bring to higher education (Abbot, 2017; Cook-Sather \& Luz, 2015). Such relationships, in the hierarchical context of higher education, can rarely be equal (as power is always omnipresent) but can strive for promoting equity. Importantly, such partnerships are underpinned by principles of respect, reciprocity and shared responsibility (Cook-Sather et al., 2014). Such themes in partnership discussions have thus far situated partnership work squarely within the realms of social justice.

The conceptualisation of students as partners work extends beyond the daily actions of students contributing to their educational experiences through voice or social co-production to fundamentally reenvision spaces of higher education (Cook-Sather et al., 2014; Matthews, Cook-Sather, \& Healey, 2018). Healey, Flint, and Harrington $(2014 ; 2016)$ distinguish four categories of partnership practice: learning, teaching, and assessment; scholarship of teaching and learning; curriculum design and pedagogic consultancy; and subject-based research. Emerging research suggests, however, that if partnership is considered to be a mindset that underlies practices (Peseta et al., in press), then making such categorical differentiations between partnership working does not always reflect the ways in which practitioners themselves describe their practices (Abbot, 2018; Mercer-Mapstone \& Bovill, 2019). It is this concept of partnership as a mindset or an ethos (rather than solely a mode of practice) that seems to distinguish the metaphor of student as partner from the metaphor of student as co-creator. There is significant overlap between the metaphors in literature - for example, that both processes advocate the adoption of values such as trust and respect. In our experiences of working with practitioners, however, the on-the-ground adoption of terms seems to differ such that co-creation is often deployed as a contained process to achieve a certain outcome (such as the co-creation of a curricular resource), whereas partnerships seem to be used in more expansive or diffuse ways, which points to greater breadth.

Scholars often intentionally differentiate between partnership and consumerism, seeing partnership as a pushback against neoliberal perspectives (Matthews, Dwyer, Russell, \& Enright, 2018; Wijaya Mulya, 2019). As a distinction, literature referring to students as co-creators often uses language such as resources, innovation, and value (e.g., Fagerstrøm \& Ghinea, 2013; Judson \& Taylor, 2014), which is markedly not seen in the literature on students as partners. In the dialogue below, however, we challenge the divisions that exist between the numerous metaphors and question the range of intentions that drive practitioners to adopt different engagement and partnership practices. We also raise questions as to whether the same values that underpin the involvement of students as partners, such as respect, reciprocity, and shared responsibility (Cook-Sather et al., 2014), could, in some contexts, align with neoliberal perspectives, thus suggesting that these two ideologies may not be mutually exclusive.

\section{Students as change agents}

The term students as change agents describes processes akin to those in partnership but places the leadership and agency squarely within the student's domain (Kay et al., 2010). Many partnerships in higher education are staff initiated (Cook-Sather et al., 2014), and this is reflected in an over- 
representation of staff authoring partnership scholarship, raising questions about the extent to which the reciprocity that is core to partnership actually extends into how the field is being shaped through academic discourses (Mercer-Mapstone et al., 2017). The positioning of students as change agents addresses this issue by advocating for and describing work that is initiated, designed, and led by students - either alone, with other students, or with staff (Dunne \& Zandstra, 2011). One example of students as change agents is described by Kay, Owen, and Dunne (2012), where a group of mathematics students explored how technology could be used in their curriculum-designing original resources and measuring student engagement and satisfaction with those resources. It is interesting to note the link here to earlier discussions about satisfaction being a common metric within the context of the metaphor of students as consumers. By measuring student satisfaction with learning resources created though change-agent initiatives, we begin to see the intertwined relationships between these various metaphors.

A further argument for the importance of students' agency in shaping their own higher education experiences is to redress the frequent positioning of students as objects in higher education research and practice - rather than as responsible and valuable participants and agents (Felten et al., 2019). While such approaches to engaging students may indeed boost the metrics of student satisfaction that are frequently aligned with neoliberal rationales, these outcomes are not the goal, focus, or intended outcome of such work. Instead, both partnership and students as change agents focuses on the inherent value in the process of engagement and, with discussions of individual and collective power and agency, seem to be almost exclusively aligned with social justice rationales for engaging students. This argument presents a direct pushback against the positioning of students as consumers and can be seen to be the most radical (and resultantly, also the rarest) form of the different student roles described here.

\section{A DIALOGUE BETWEEN TWO DISTINCT RATIONALES UNDERPINNING STUDENTS' CHANGING ROLES}

In this section, we engage in dialogue around the different rationales that we each bring to these debates-neoliberalism and social justice. We have touched upon these underpinnings in the above sections. Recent research on student engagement in higher education has most often situated research in the frame of social justice, for example, along the Freirean line of thought as education for liberation (Peters \& Matthias, 2018), to bring democratic values to higher education (Lubicz-Nawrocka, 2018), and even at odds with neoliberalism (Dwyer, 2018). Thus, we have chosen to focus predominantly on the affordances and limitations of neoliberalism as an engagement stance in our discussion to address this gap in the literature - and to explore the interstices between the two. Our choice to do so in dialogic genre reflects the iterative and process-oriented nature of the fields in which we work.

\section{Bridging differences and discovering interstices through dialogue}

Lucy

So, I have to say that when I first read your work situating partnership within and for neoliberal contexts, I struggled with it! In arguing for a neoliberal view of engagement through the metaphor of students as co-creators, I felt like what you were saying went against everything that I stood for. As I had always used the related metaphor of students as partners from a social justice stance, I felt like you were co-opting the term co-creation for neoliberal aims. Indeed, many seem to agree with me in that cocreation and partnership with students, for example, are often positioned to contest the neoliberalization 
of higher education (for example, see Wijaya Mulya, 2018). The term also taps into bigger societal fears and issues about rising economic inequality and policies that protect the interests of corporations over people. In higher education, some might see that neoliberalism encourages practices that can undermine the freedom of faculty and the value of learning as a social value rather than just a step to economic opportunity. Is that a reaction you come across often? Can you tell me a bit more about your rationale?

\section{Mollie}

There are well-known fears and resistance towards the growing neoliberalism in higher education (e.g., Furedi, 2010; Giroux, 2002). Neoliberal values such as self over community and unequal privilege have further been linked to negative consequences in education contexts, for example, increases in student cheating (Pulfrey \& Butera, 2013). It is also important to recognize that the term neoliberalism often sparks emotive and personal responses, as neoliberalism affects (and often negatively) far more than just the higher education context. These are critical issues to acknowledge in such discussions.

Neoliberalism in its most simplified sense is the removal of barriers or obstacles that allow for a free market (Birch, 2017). This manifests in higher education in a multitude of ways, from deregulation to privatization and the rise of market orientation (Brown, 2018). Some of the effects of these are negative, but a proponent of neoliberalism might argue that some are good. Neoliberalism allows more universities to enter the marketplace (including alternative models) and may propel existing universities to reflect on what potential and current students want. Therefore, a neoliberal rationale (i.e., one emphasizing the free market and individualism) could be used both as a basis to help the university increase profits and as a rationale to improve the student experience. For example, within higher education, supporting a free market can be used as a rationale to remove caps on the number of students that universities can enroll. This act of neoliberalism actually can align to theories of social justice as it has the potential to increase the diversity of student cohorts by offering more student places (Harvey, Burnheim, \& Brett, 2016; Norton, 2013). The same could be illustrated through student co-creation. Emphasis on listening to your students' preferences and their individual voices could be both situated within a neoliberal rationale that results in the enhancement of services at the university (e.g., Dollinger, Lodge \& Coates, 2018) and seen as a means to achieve social justice or legitimation of student voices.

\section{Lucy}

It is interesting hearing how you approach the same practices that I adopt from such a vastly different angle. As I said, I used to react in the same ways as the people you describe-rejecting the neoliberal premise entirely as "bad." I happily acknowledge that my reaction was based on a superficial understanding. It was not until I heard students themselves using neoliberal arguments to advocate for better student engagement that I began to question my assumptions. For example, at a student engagement conference, I spoke with a student who explained to me that she was unhappy with the ways that the majority of her teachers engaged students in their classes and that, given how much she pays for her university degree, she wanted deeper engagement and ways to actively shape her experiences so that she could make the absolute most of her studies. It was interesting (and a bit shocking) for me to hear a student finding agency in the consumerist language that has been argued to encourage passivity in students regarding their learning in higher education (McCulloch, 2009). When I did more reading, I found research that pointed out that in a sample of 1,000 UK students, 53 percent identify themselves as 
customers of their university (Universities UK, 2017). It made me reconsider the different ways that individuals come to practices such as partnership and how perhaps we should not dismiss certain motivations lest we risk excluding large numbers of people. How do you think these rationales affect resultant practices?

\section{Mollie}

I think the frames or rationales that underpin co-creation or students as partners work likely have implications for how that work unfolds. For example, if you are creating a student-staff magazine to recruit new students and keep alumni in touch (i.e., market orientation), you may be less concerned with the relationships in place and the value system of the group than you are with getting it done on time for distribution (Dollinger, 2018a). Similarly, if many of your student partners are engaging in the project to enhance their employability, they may be overly outcomes or awards-focused. I am not convinced it is problematic if staff pursue co-creation for neoliberal, even self-interested reasons, or likewise, if students engage for payment or to strengthen their CV. However, we need to acknowledge how the various frames to engage with co-creation may modify the type of co-creation that is occurring. Indeed, large numbers of students are also drawn to students as partners work for employability reasons (Marquis, Jayaratnam, Mishra, \& Rybkina, 2018). These initiatives may unfold in a different way than staff who engage with student as partners work within a frame of social justice-for example, to redress social inequities in higher education (e.g., Bindra et al. 2018).

\section{Lucy}

Do you think researchers and students have to choose between neoliberal and social justice frames when using the five metaphors above?

\section{Mollie}

No, not necessarily. I think researchers need to be clear if they have a bias or specific history with one frame versus another. However, an informed study or project could situate the metaphor within both frames and see outcomes that align to both frames. For example, a students as partners project that both helps support recruitment for the university (e.g., through promotional videos) and that also genuinely changes the way staff and students see and treat each other with more respect within that partnership. But as of now, I feel there is a lot of fear within student partnership work about encroaching neoliberal or market-oriented values. Would you agree?

Lucy

I think there is, at least in my case, a fear that the language of active, authentic student engagement will be co-opted for neoliberal agendas-empty lip-service to "sell" the "product" of education to more students - or selling the students as products themselves. The result of such tokenistic rhetoric risks raising certain expectations only to be met with a different experience entirelyone that potentially disappoints and is not based on what is best for students' learning. If I were to adopt consumerist terms, this might be like buying a beautifully advertised dress online only to find when it is delivered that it is flimsy and poorly made. Does that make sense? As Healey and Healey (2018, p. 6) write, "There is a danger, however, that some managers and policy makers may attempt to highjack the 
term partnership to mean increased choice for students in the higher education marketplace, rather than recognize that [students as partners] work is a counter-reaction to the neo-liberal, competition-driven, student as customer policies promoted by many governments."

\section{Mollie}

I think that is a fair concern. In literature, we often see scholars note that market ideology is inconsistent with democratic values in higher education (e.g., Marginson, 2007), and I am not disagreeing with that. But I am wondering if the two are not as polarized as we might think. For example, do the concepts of students as partners or student-staff co-creation always have to be counterreaction to the neoliberal standpoint? Could a social justice frame be intertwined within neoliberalism? And if staff or students are motivated by neoliberal aims, how might that affect the work?

\section{Lucy}

I am coming to see that as a possibility, particularly in examples like the one you mentioned earlier. A similar example from my practice was my experience of co-leading the design of an institutionwide students-as-partners program (see Mercer-Mapstone \& Clarke, 2018). It was clear from the institutional standpoint an important output and measure of that program was to increase student engagement metrics such as satisfaction. While taking this into account, the team designing the program was also focused on ensuring that the students and staff engaging in the future program would be supported to engage in an authentic partnership_one in which they would be treated with respect and all contributions would be equally valued in ways that create community and drive a sense of belonging for all students and staff. In that case, social justice rationales were indeed intertwined with neoliberal motivations. I think, in such cases, we do need to be careful that one rationale does not supersede or obscure the other. Carey (2013), for example, found that when students are engaged through a predominantly consumerist lens, they are likely to be seen only as data sources by institutions. Where multiple rationales or lenses exist, consideration needs to be given to how the engagement remains authentic and for the benefit of students themselves.

In part, the positioning of partnership, co-production, or change agents as a counter-narrative to neoliberalism makes sense to me because it can be a strong pushback against the positioning of students as consumers, which I do still think is problematic. However, I have come to see that the problem with going down this road is that we are setting up a false binary for why people engage in these practices: an either/or situation. I do not think such binaries are ever useful and they certainly never reflect the reality of human motivations and experience (take gender binaries for example!).

Say a teacher decides to adopt co-produce an assessment task within her class. She does so because she has read that such approaches can increase students' employability and can be more fun and engaging for both her and the increasing diversity of students in her course. Employability arguably is a product-focused term used for neoliberal rhetoric. Yet she also is choosing partnership because the process itself is rewarding and beneficial for individuals. So, what is her rationale? Neoliberal- or valuesoriented? I would argue it is somewhere in between — or both. Ultimately, I think what is important are the practices that result from these motivations. For example, I came to partnership work as a student because it was a paid opportunity: money was my original motivation (and can you get more neoliberal than that?). Yet, when I engaged in honest and open dialogue with my staff partners in ways that 
examined our assumptions and felt equitable in terms of value and contribution I came to believe in the value of partnership and my motivations changed. So, while I still see partnership as a pushback against tokenistic neoliberal rhetoric, I guess I have come to see value in acknowledging and respecting the diversity of motivations that people bring to engagement in higher education.

\section{CONCLUDING REMARKS AND FUTURE QUESTIONS}

Our intention in this article is to unpack the various terms used to conceptualize students' changing roles in higher education. We do so through the lens of two distinct rationales underpinning student engagement work, one rooted in social justice, and the other in neoliberalism. We acknowledge the two lenses we bring to this discussion are not all-inclusive and we look forward to future work that contributes similar analyses from alternate perspectives.

Writing this article has been a learning experience as much for us as for our intended readerschallenging our own assumptions and the biases we held. From our discussion, we have come to several takeaways, but also a new range of questions for future research. As our dialogue explored, there is great diversity within the student engagement space, not only in the metaphors we use to describe our practices, but also in the rationales and perspectives that underlie these practices. Yet what brings us together are common goals to improve students' learning and experiences. This is a critical point to reflect upon, especially given that some of the potentially divisive or binarizing distinctions researchers use to differentiate our practices are not always recognized nor accepted by students. For example, while some scholars and practitioners may reject the metaphor of student as consumers within the realms of student engagement, students may not-indeed, this may actually be a source of agency for some students. This tension needs acknowledgement and consideration so that our assumptions do not close off pathways to engaging students in ways that are relevant for them.

We also highlight that anti-neoliberalism in higher education can be supported through fears that student engagement and partnership will become tokenistic, as has been discussed elsewhere (Bell \& Peseta, 2016; Healey \& Healey, 2018; Wijaya Mulya, 2018). This is a credible fear. However, it is also a reality that the increasing prevalence of neoliberalism in higher education will be a key determining factor in the support and growth of student engagement initiatives. Ultimately, it may be up to practitioners and researchers to consider how they can harness the changes that accompany the reality of neoliberalism in higher education (e.g., university's goals to increase fee-paying students) to drive change at levels where such narratives resonate (with senior administrators, for example) while also ensuring authentic practices on the ground.

We thus pose to you a number of questions for future exploration and consideration: How do other different underlying viewpoints, beyond neoliberalism and social justice, shape students' roles in higher education? Can practice driven by neoliberalism align with the core values of, for example, students as partners - such as respect, reciprocity, and shared responsibility? How can the numerous communities researching students' roles and experiences in higher education better engage in dialogue across differences?

\section{ACKNOWLEDGMENTS}

Thanks to Amani Bell and to the anonymous reviewers for their feedback, which helped improve this manuscript. 
Mollie Dollinger is Associate Lecturer at La Trobe University (AUS). She leads the Student Partnership portfolio and works across various initiatives to support and strengthen student voices.

Lucy Mercer-Mapstone is Lecturer in Higher Education Learning Design at the University of Technology Sydney (AUS). She specialises in academic development and inclusive pedagogies.

\section{REFERENCES}

Abbot, S. (2017). Book review of Teaching to transgress: Education as the practice of freedom. International Journal for Students As Partners, 1(2). https://doi.org/10.15173/ijsap.v1i2.3230

Abbot, S. (2018). A continuum of research: Assistants, partners, and undergraduate researchers. [Web log post]. Retrieved from https://www.centerforengagedlearning.org/a-continuum-of-research-assistantspartners-and-undergraduate-researchers/

Amineh, R. J., \& Asl, H. D. (2015). Review of constructivism and social constructivism. Journal of Social Sciences, Literature and Languages, 1(1), 9-16. Retrieved from http://www.blueap.org/j/List/4/iss/volume\%201\%20(2015)/issue\%2001/2.pdf

Australian National University. (2017). Student partnership agreement. Retrieved from https://anusa.com.au/advocacy/studentpartnerships/

Barnacle, R., \& Dall'Alba, G. (2017). Committed to learn: student engagement and care in higher education. Higher Education Research \& Development, 36(7), 1326-1338. https://doi.org/10.1080/07294360.2017.1326879

Bell, A., \& Peseta, T. (2016). Students as partners: A way to re-shape higher education pedagogy or neoliberal seduction? Paper presented at the Higher Education Research and Development Society of Australasia, Freemantle, Australia.

Bindra, G., Easwaran, K., Firasta, L., Hirsch, M., Kapoor, A., Sosnowski, A., ... Vatansever, G. (2018). Increasing representation and equity in students as partners initiatives. International Journal for Students $A s$ Partners, 2(2), 10-15. https://doi.org/10.15173/ijsap.v2i2.3536

Birch, K. (2017, November 2). What exactly is neoliberalism? [Web log post]. Retrieved from https://theconversation.com/what-exactly-is-neoliberalism-84755

Bovill, C., Cook-Sather, A., \& Felten, P. (2011). Students as co-creators of teaching approaches, course design, and curricula: Implications for academic developers. International Journal for Academic Development, 16(2), 133-145. https://doi.org/10.1080/1360144X.2011.568690

Brennan, J., \& Naidoo, R. (2008). Higher education and the achievement (and/or prevention) of equity and social justice. Higher Education, 56(3), 287-302. https://doi.org/10.1007/s10734-008-9127-3

Brown, R. (2018). Everything for sale? Neoliberalism, marketisation and higher education. Retrived from https://www.solent.ac.uk/news/life-at-solent/2018/everything-for-sale-neoliberalism-marketisationand-higher-education

Carey, P. (2013). Representation and student engagement in higher education: A reflection on the views and experiences of course representatives. Journal of Further and Higher Education, 37(1), 71-88. https://doi.org/10.1080/0309877X.2011.644775

Connell, R. (2013). The neoliberal cascade and education: An essay on the market agenda and its consequences. Critical Studies in Education, 54(2), 99-112. https://doi.org/10.1080/17508487.2013.776990

Cook-Sather, A., \& Alter, Z. (2011). What is and what can be: How a liminal position can change learning and teaching in higher education. Anthropology \& Education Quarterly, 42(1), 37-53. https://doi.org/10.1111/j.1548-1492.2010.01109.x

Cook-Sather, A., Bovill, C., \& Felten, P. (2014). Engaging students as partners in learning and teaching: A guide for faculty. San Francisco, CA: Josey-Bass.

Cook-Sather, A., \& Luz, A. (2015). Greater engagement in and responsibility for learning: What happens when students cross the threshold of student-faculty partnership. Higher Education Research \& Development, 34(6), 1097-1109. https://doi.org/10.1080/07294360.2014.911263 
Dollinger, M. M. (2018a). Co-creation in higher education (Unpublished doctoral dissertation). University of Melbourne. http://hdl.handle.net/11343/217993

Dollinger, M. M. (2018b). Higher education's value: In the experience itself. In Research and Development in Higher Education: [Re] Valuing Higher Education. Vol. 41 (pp. 60-68). Hammondville: Higher Education Research and Development Society Association. Retrieved from http://www.herdsa.org.au/publications/conference-proceedings/research-and-development-highereducation-re-valuing-higher-5

Dollinger, M., \& Brown, J. (2019). An institutional framework to guide the comparison of work-integrated learning. Journal of Teaching and Learning for Graduate Employability, 10(1), 88-100. https://doi.org/10.21153/jtlge2019vol10no1art780

Dollinger, M., Lodge, J., \& Coates, H. (2018). Co-Creation in Higher Education: Towards a Conceptual Model. Journal of Marketing for Higher Education, 28(2), 210-231. https://doi.org/10.1080/08841241.2018.1466756

Dunne, E., \& Zandstra, R. (2011). Students as change agents: New ways of engaging with learning and teaching in higher education. Bristol: Higher Education Academy. Retrieved from http://escalate.ac.uk/downloads/8247.pdf

Dwyer, A. (2018). Toward the formation of genuine partnership spaces. International Journal for Students as Partners, 2(1), 11-15. https://doi.org/10.15173/ijsap.v2i1.3503

Elon University (2018). Students as partners. Retrieved from https://www.centerforengagedlearning.org/doingengaged-learning/students-as-partners/

Fagerstrøm, A., \& Ghinea, G. (2013). Co-creation of value in higher education: Using social network marketing in the recruitment of students. Journal of Higher Education Policy and Management, 35(1), 45-53. https://doi.org/10.1080/1360080X.2013.748524

Felten, P., Abbot, S., Kirkwood, J., Long, A., Lubicz-Nawrocka, T., Mercer-Mapstone, L., Verwoord, R. (2019). Reimagining the place of students in academic development. International Journal for Academic Development, 24(2), 192-203. https://doi.org/10.1080/1360144X.2019.1594235

Freire, K., \& Sangiorgi, D. (2010). Service design and healthcare innovation: From consumption to coproduction and co-creation. Paper presented at the Second Nordic Conference on Service Design and Service Innovation, Linköping, Sweden. Retrieved from http://148.88.47.13/html/imagination/sites/default/files/outcome downloads/servdes2010 freiresangi orgi.pdf

Freire, P. (1972). Pedagogy of the oppressed. London, UK: Penguin Books.

Furedi, F. (2010). Introduction. In M. Molesworth, E. Nixon, \& R. Scullion (Eds.), The marketisation of higher education and the student as consumer (pp. 15-22). London: Routledge.

Giroux, H. (2002). Neoliberalism, corporate culture, and the promise of higher education: The university as a democratic public sphere. Harvard Educational Review, 72(4), 425-464. https://doi.org/10.17763/haer.72.4.0515nr62324n71p1

Hammersley, L., Lloyd, K., \& Bilous, R. (2018). Rethinking the expert: Co-creating curriculum to support international work-integrated learning with community development organisations. Asia Pacific Viewpoint, 59(2), 201-211. https://doi.org/10.1111/apv.12190

Harvey, L. (2001). Defining and measuring employability. Quality in Higher Education, 7(2), 97-109. https://doi.org/10.1080/13538320120059990

Harvey, A., Burnheim, C., \& Brett, M. (2016). Towards a fairer chance for all: Revising the Australian student equity framework. In Student Equity in Australian higher education: Twenty-five years of A Fair Chance for All (pp. 3-20). Singapore: Springer.

Healey, M., Flint, A., \& Harrington, K. (2014). Engagement through partnership: Students as partners in learning and teaching in higher education. York: Higher Education Academy. Retrieved from https://www.heacademy.ac.uk/system/files/resources/engagement through partnership.pdf

Healey, M., Flint, A., \& Harrington, K. (2016). Students as partners: Reflections on a conceptual model. Teaching \& Learning Inquiry, 4(2), 1-13. https://doi.org/10.20343/teachlearninqu.4.2.3 
Healey, M., \& Healey, R. L. (2018). "It depends": Exploring the context-dependent nature of students as partners' practices and policies. International Journal for Students as Partners, 2(1), 1-10. https://doi.org/10.15173/ijsap.v2i1.3472

Hennig-Thurau, T., Langer, M. F., \& Hansen, U. (2001). Modeling and managing student loyalty: An approach based on the concept of relationship quality. Journal of Service Research, 3(4), 331-344. https://doi.org/10.1177/109467050134006

hooks, b. (1989). Feminist scholarship: Ethical issues. In Talking back: Thinking feminist, thinking black (pp. 42-48). London: Sheba Feminist.

Judson, K. M., \& Taylor, S. A. (2014). Moving from marketization to marketing of higher education: The cocreation of value in higher education. Higher Education Studies, 4(1), 51-67. http://dx.doi.org/10.5539/hes.v4n1p51

Kay, J., Dunne, E., \& Hutchinson, J. (2010). Rethinking the values of higher education — Students as change agents? Gloucester: QAA and University of Exeter. Retrieved from https://dera.ioe.ac.uk/1193/1/StudentsChangeAgents.pdf

Kay, J., Owen, D., \& Dunne, E. (2012). Students as change agents: Student engagement with quality enhancement of learning and teaching. In A. R. I. Solomonides \& P. Petocz (Eds.), Engaging with learning in higher education (pp. 359-380). Oxfordshire: Libri Publishers.

Keegan, H., \& Bell, F. (2011). YouTube as a repository: The creative practice of students as producers of Open Educational Resources. European Journal of Open and Distance e-Learning. Retrieved from http://usir.salford.ac.uk/id/eprint/19282/2/Keegan Bell_Creativity and OER.docx.pdf

Kleinsmann, M., \& Valkenburg, R. (2008). Barriers and enablers for creating shared understanding in co-design projects. Design Studies, 29(4), 369-386. https://doi.org/10.1016/j.destud.2008.03.003

Kotzé, T. G., \& du Plessis, P. J. (2003). Students as "co-producers" of education: A proposed model of student socialisation and participation at tertiary institutions. Quality Assurance in Education, 11(4), 186-201. https://doi.org/10.1108/09684880310501377

Kuh, G., O'Donnell, K., \& Schneider, C. G. (2017). HIPs at ten. Change: The Magazine of Higher Learning, 49(5), 8-16. https://doi.org/10.1080/00091383.2017.1366805

La Trobe University (2018). 2018-2022: Student success and retention strategy. Retrievied from https://www.latrobe.edu.au/ data/assets/pdf file/0011/979436/Student-Success-and-Retention-Plan2018-2022.pdf

Lee, M. J., McLoughlin, C., \& Chan, A. (2008). Talk the talk: Learner-generated podcasts as catalysts for knowledge creation. British Journal of Educational Technology, 39(3), 501-521. https://doi.org/10.1111/j.14678535.2007.00746.x

Loch, B., \& Lamborn, J. (2016). How to make mathematics relevant to first-year engineering students: perceptions of students on student-produced resources. International Journal of Mathematical Education in Science and Technology, 47(1), 29-44. https://doi.org/10.1080/0020739X.2015.1044043

Lubicz-Nawrocka, T. (2018). Students as partners in learning and teaching: The benefits of co-creation of the curriculum. International Journal for Students as Partners, 2(1), 47-63. https://doi.org/10.15173/ijsap.v2i1.3207

Marginson, S. (2007). The public/private divide in higher education: A global revision. Higher Education, 53(3), 307-333. https://doi.org/10.1007/s10734-005-8230-y

Marquis, E., Jayaratnam, A., Mishra, A., \& Rybkina, K. (2018). "I feel like some students are better connected": Students' perspectives on applying for extracurricular partnership opportunities. International Journal for Students as Partners, 2(1), 64-81 https://doi.org/10.15173/ijsap.v2i1.3300

Matthews, K. E., Cook-Sather, A., Acai, A., Dvorakova, S. L., Felten, P., Marquis, E., \& Mercer-Mapstone L. (2019). Toward theories of partnership praxis: an analysis of interpretive framing in literature on students as partners in teaching and learning. Higher Education Research \& Development, 38(2), 1-14. https://doi.org/10.1080/07294360.2018.1530199

Matthews, K. E., Cook-Sather, A., \& Healey, M. (2018). Connecting learning, teaching and research through student-staff partnerships: Toward universities as egalitarian learning communities In V. C. H. Tong, A. Standen, \& M. Sotiriou (Eds.), Shaping higher education with students: Ways to connect research and teaching (pp. 23-29). London: University College London Press. 
Matthews, K. E., Dwyer, A., Russell, S., \& Enright, E. (2018). It is a complicated thing: Leaders' conceptions of students as partners in the neoliberal university. Studies in Higher Education. Advance online publication. https://doi.org/10.1080/03075079.2018.1482268.

McCulloch, A. (2009). The student as co-producer: Learning from public administration about the studentuniversity relationship. Studies in Higher Education, 34(2), 171-183. https://doi.org/10.1080/03075070802562857

McMaster University (2018). Students partners program. Retrieved from https://mi.mcmaster.ca/studentpartners-program/

McMillan, J. J., \& Cheney, G. (1996). The student as consumer: The implications and limitations of a metaphor. Communication Education, 45(1), 1-15. https://doi.org/10.1080/03634529609379028

Mercer-Mapstone, L., \& Bovill, C. (2019). Equity and diversity in institutional approaches student-staff partnership schemes in higher education. Studies in Higher Education. Advance online publication. https://doi.org/10.1080/03075079.2019.1620721

Mercer-Mapstone, L., \& Clarke, A. (2018). A partnership approach to scaling up student/staff partnership at a large research-intensive university. Journal of Educational Innovation, Partnership and Change, 4(1). http://dx.doi.org/10.21100/jeipc.v4i1.741

Mercer-Mapstone, L., Dvorakova, S. L., Matthews, K. E., Abbot, S., Cheng, B., Felten, .. Swaim, K. (2017). A systematic literature review of students as partners in higher education. International Journal for Students as Partners, 1(1). https://doi.org/10.15173/ijsap.v1i1.3119

Mercer-Mapstone, L., \& Mercer, G. (2018). A dialogue between partnership and feminism: Deconstructing power and exclusion in higher education. Teaching in Higher Education, 23(1), 137-143. https://doi.org/10.1080/13562517.2017.1391198

Minnich, E. (2018). People who are not thinking are capable of anything: What are students learning, how are students learning it, and does it make them better people. Paper presented at the International Society for the Scholarship of Teaching and Learning, Bergen, Noway.

Monroe, K. B. (1973). Buyers' subjective perceptions of price. Journal of Marketing Research, 10(1), 70-80. https://www.jstor.org/stable/3149411

Morgan, G. (2006). Images of organization. (Updated ed.) Thousand Oaks, CA: Sage.

Neary, M. (2014). Student as producer: Research-engaged teaching frames university-wide curriculum development. Council on Undergraduate Research Quarterly, 35(2), 28-35. Retrived from https://go.galegroup.com/ps/i.do?id=GALE\%7CA465436397\&sid=googleScholar\&v=2.1\&it=r\&linkacces $s=$ fulltext\&issn=10725830\&p=AONE\&sw=w\&userGroupName=latrobe

Neary, M., \& Winn, J. (2009). The student as producer: Reinventing the student experience in higher education. In L. Bell, H. Stevenson, \& M. Neary (Eds.) The future of higher education: Policy, pedagogy and the student experience (pp. 126-38). London: Continuum.

Norton, A. (2013). Keep the caps off! Student access and choice in higher education. Melbourne: Grattan Institute. Retrieved from https://grattan.edu.au/wp-content/uploads/2014/03/195-Keep-the-capsoff.pdf

Peseta, T., Pizzica, J., Beathe, A., Jose, C., Lynch, R., Manthos, M., ... and Raza, H. (in press). A partnership mindset: Students as partners for and beyond the university. In L. Mercer-Mapstone \& S. Abbot (Eds.), The power of student-staff partnerships: Revolutionizing higher education. Center for Engaged Learning Open-Access Book Series. Elon, NC: Center for Engaged Learning.

Peters, J., \& Mathias, L. (2018). Enacting student partnership as though we really mean it: Some Freirean principles for a pedagogy of partnership. International Journal for Students as Partners, 2(2), 53-70. https://doi.org/10.15173/ijsap.v2i2.3509

Prahalad, C. K., \& Ramaswamy, V. (2004). Co-creation experiences: The next practice in value creation. Journal of Interactive Marketing, 18(3), 5-14. https://doi.org/10.1002/dir.20015

Pulfrey, C., \& Butera, F. (2013). Why neoliberal values of self-enhancement lead to cheating in higher education: A motivational account. Psychological Science, 24(11), 2153-2162. https://doi.org/10.1177/0956797613487221

Sanders, L., \& Simons, G. (2009). A social vision for value co-creation in design. Technology Innovation Management Review. https://timreview.ca/article/310 
Sanders, E. B. N., \& Stappers, P. J. (2014). Probes, toolkits and prototypes: three approaches to making in codesigning. CoDesign, 10(1), 5-14. https://doi.org/10.1080/15710882.2014.888183

Seale, J. (2009). Doing student voice work in higher education: an exploration of the value of participatory methods. British Educational Research Journal, 36(6), 995-1015. https://doi.org/10.1080/01411920903342038

Seale, J., Gibson, S., Haynes, J., \& Potter, A. (2015). Power and resistance: Reflections on the rhetoric and reality of using participatory methods to promote student voice and engagement in higher education. Journal of Further and Higher Education, 39(4), 534-552. https://doi.org/10.1080/0309877X.2014.938264

Shah, M., \& Nair, C. S. (2006). Translating student voice into action: a case study at two Australian universities. In Proceedings of the Australian Universities Quality Forum 2006: Quality outcomes and diversity, Perth, Australia, 5-7 July 2006 (pp. 139-150). Melbourne: Australian Universities Quality Agency.

Singleton-Jackson, J. A., Jackson, D. L., \& Reinhardt, J. (2010). Students as consumers of knowledge: Are they buying what we're selling? Innovative Higher Education, 35(5), 343-358. https://doi.org/10.1007/s10755010-9151-y

Smith, B. (2000). The challenge of making ends meet in postgraduate research training. G. P. Mullins \& M. Kiley (Eds.) Quality in postgraduate research: Making ends meet (pp. 25-29). Adelaide: Advisory Centre for University Education.

Tilak, J. (2015). Global trends in funding higher education. International Higher Education, 42, 5-6. https://doi.org/10.6017/ihe.2006.42.7882

University of Queensland. (2016). Student strategy 2016-2020 white paper. Retrieved from https://studentstrategy.uq.edu.au/files/453/Student-Strategy White-Paper.pdf

University of Edinburgh. (2018). Student partnership agreement. Retrieved from https://www.ed.ac.uk/students/academic-life/student-voice/partnership-agreement

Universities UK (2017). Education, consumer rights and maintaining trust: What students want from their university. London: Universities UK. Retrieved from https://www.universitiesuk.ac.uk/policy-andanalysis/reports/Documents/2017/education-consumer-rights-maintaining-trust-web.pdf

Varnham, S. (2017). Creating a national framework for student partnership in university decision-making and governance: A toolkit for embedding student partnership in your institution. Retrieved from https://www.uts.edu.au/sites/default/files/article/downloads/toolkit\%20291117.pdf

Western Sydney University. (2018). Student curriculum partners. Retrieved from https://www.westernsydney.edu.au/learning futures/home/21st century curriculum project $2 / 21 \mathrm{C} \mathrm{cu}$ rriculum project/future of work/students as partners

Wijaya Mulya, T. (2019). Contesting the neoliberalisation of higher education through student-faculty partnership. International Journal for Academic Development, 24(1), 86-90. https://doi.org/10.1080/1360144X.2018.1520110

Woodall, T., Hiller, A., \& Resnick, S. (2014). Making sense of higher education: Students as consumers and the value of the university experience. Studies in Higher Education, 39(1), 48-67. https://doi.org/10.1080/03075079.2011.648373 